Editors' Note: Charrel questions the history and diagnosis of the patient presented in Oechtering and Petzold's article on hydrocephalus following Toscana virus meningoencephalitis. The authors defend their approach and clarify the patient's travel history while educating readers about sandfly behavior in the Umbrian region of Italy. Merkies argues that the negative results of the Tafamidis for transthyretin amyloid study were influenced by methodologic aspects including the rationale and weight of the endpoints. He explains that reanalyzing the data using the Rasch method may yield more accurate results and concludes that modern clinimetric-based outcome measures studies should precede interventional trials.

Chafic Karam, MD, and Robert C. Griggs, $M D$

\section{ACUTE HYDROCEPHALUS DUE TO IMPAIRED CSF RESORPTION IN TOSCANA VIRUS MENINGOENCEPHALITIS}

Remi N. Charrel, Marseilles, France: Oechtering and Petzold ${ }^{1}$ report a patient with acquired hydrocephalus due to Toscana virus (TOSV) after visiting Umbria, Italy. First, TOSV is only transmitted by sandflies (Phlebotomus perniciosus and P perfiliewi), so it is confusing to report multiple tick bites without mentioning sandflies. Second, the time period should be mentioned since sandflies circulate seasonally, with population density peaking in late August-September in Umbria. Third, the statement “... travel history unremarkable" is puzzling since TOSV is present in an extremely wide geographic area including southern Europe, North Africa, and the Middle East, so potential past infection should be considered. Fourth, the techniques for immunoglobulin $\mathrm{G}$ (IgG) and immunoglobulin $M(\operatorname{IgM})$ detection and titration are not included, and the very high IgG titers are surprising so early after the clinical onset (less than 10 days). Fifth, according to the WHO definition, the biological parameters are compatible with a probable TOSV infection, not with confirmed acute TOSV (absence of seroconversion and of direct detection of TOSV). ${ }^{2}$ Reactivation of past TOSV infection could explain the serologic profile. Among pathogens causing hydrocephalus, lymphocytic choriomeningitis virus infection is plausible and has been shown to cause acquired hydrocephalus. ${ }^{3}$
Author Response: Gabor C. Petzold, Bonn; Johanna Oechtering, Berlin: We thank Dr. Charrel for his comments. First, we clearly state that TOSV is transmitted by sandflies. However, when faced with a patient with acute meningoencephalitis after a camping trip, most neurologists (and arguably most doctors in general) will consider tick-borne diseases such as borreliosis or tick-borne encephalitis when multiple tick bites are reported. Our case demonstrates that a history of tick bites can be misleading in some patients, and we therefore found it important to report the complete patient history. Second, our patient took his trip to Umbria in August, which is the peak of sandfly population density in that region. Third, the patient had not traveled to any other countries where TOSV is endemic. Therefore, his travel history was unremarkable. Fourth, IgG and IgM were detected by indirect immunofluorescence assay. While we agree that the IgG titers are unusually high, the unremarkable past travel history makes reactivation of a previous infection unlikely. Fifth, we agree that our patient fulfills the diagnosis of probable TOSV infection according to WHO criteria. Finally, we had tested our patient serologically for lymphocytic choriomeningitis virus, but the results were negative.

\section{(C) 2013 American Academy of Neurology}

1. Oechtering J, Petzold GC. Acute hydrocephalus due to impaired CSF resorption in Toscana virus meningoencephalitis. Neurology 2012;79:829-831.

2. Arboviral diseases, neuroinvasive and non-neuroinvasive: 2011 case definition. Available at: http://www.cdc.gov/ osels/ph_surveillance/nndss/casedef/arboviral_current.htm. Accessed August 13, 2012.

3. Charrel RN, Retornaz K, Emonet S, et al. Acquired hydrocephalus caused by a variant lymphocytic choriomeningitis virus. Arch Intern Med 2006;166:2044-2046.

TAFAMIDIS FOR TRANSTHYRETIN FAMILIAL AMYLOID POLYNEUROPATHY: A RANDOMIZED, CONTROLLED TRIAL

Ingemar S.J. Merkies, Hoofddorp, the Netherlands: Coelho et al. ${ }^{1}$ reported no significant changes in this trial even though transthyretin (TTR) was stabilized in all patients receiving Tafamidis. However, various methodologic aspects may have influenced the results.

Neither of the primary endpoints has been evaluated in familial amyloid polyneuropathy (FAP) to 


\section{Neurology}

\section{Acute hydrocephalus due to impaired CSF resorption in Toscana virus meningoencephalitis}

Remi N. Charrel, Gabor C. Petzold and Johanna Oechtering

Neurology 2013;80;1444

DOI 10.1212/WNL.0b013e31828cf551

This information is current as of April 8, 2013

\section{Updated Information \&} Services

References

Permissions \& Licensing

Reprints including high resolution figures, can be found at: http://n.neurology.org/content/80/15/1444.1.full

This article cites 2 articles, 1 of which you can access for free at: http://n.neurology.org/content/80/15/1444.1.full\#ref-list-1

Information about reproducing this article in parts (figures,tables) or in its entirety can be found online at:

http://www.neurology.org/about/about_the_journal\#permissions

Information about ordering reprints can be found online: http://n.neurology.org/subscribers/advertise

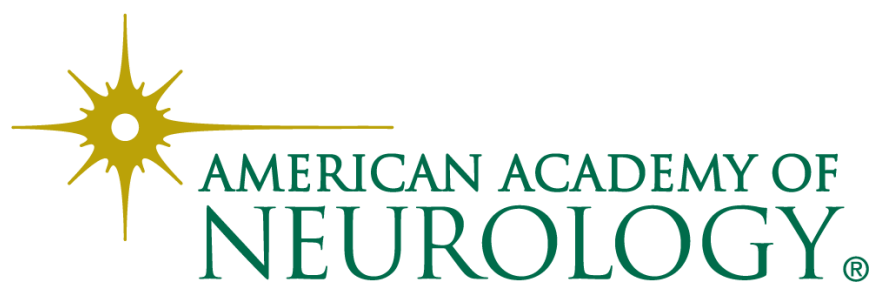

